\title{
Sobrevivência de Salmonella Enterica em Fórmulas Lácteas Infantis Sob Diferentes Condições de Armazenamento e Aquecimento.
}

\author{
Marcelo Soares de Moraes (I), Brendon Chaves Araújo (I), \\ Leonardo Emanuel de Oliveira Costa (I), Janaína dos Santos \\ Nascimento (I) \\ (I) IFRJ - Instituto Federal de Educação, Ciência e Tecnologia do RJ (Rua Senador Furtado \\ 121- Maracanã - RJ)
}

\section{Resumo}

Cronobacter spp. e Salmonella enterica são os patógenos mais preocupantes associados às fórmulas lácteas infantis (FLI), pois podem ocasionar doenças na população de risco que consome esse alimento. Muitos trabalhos relatam a sobrevivência de Cronobacter spp. nas FLI, mas um número muito reduzido trata desses aspectos quando se trata de Salmonella. Neste trabalho, duas FLI reconstituídas (F1 e F2) foram contaminadas artificialmente com a estirpe de S. enterica subsp. enterica ATCC 19214 até a concentração de 8,0 x 10 $\mathrm{ufc} / \mathrm{ml}$ e foram incubadas sob temperatura ambiente e de refrigeração. Sob temperatura ambiente, em ambas as FLI, houve um aumento de 3,3 log na população de S. enterica logo nas primeiras $24 \mathrm{~h}$ de incubação e de aproximadamente 3,8 log após 48h. Ao término de 72h, foi observado, em ambas as FLI, aumento superior a 4,5 log da concentração celular. Já sob temperatura de refrigeração, nas primeiras $48 \mathrm{~h}$ de incubação, foi detectado leve crescimento populacional (inferior a $1 \mathrm{log}$ ) e após $72 \mathrm{~h}$, observou-se crescimento similar ao das fórmulas incubadas à temperatura ambiente. Para avaliar a sobrevivência de S. enterica após o aquecimento, recipientes contendo as FLI reconstituídas foram inoculados com S. enterica de modo a atingir a concentração inicial de $10^{6} \mathrm{ufc} / \mathrm{ml}$ e foram submetidos ao aquecimento em banho-maria e em forno de micro-ondas convencional. O aquecimento em

\footnotetext{
Referência:

Marcelo Soares de Moraes, Brendon Chaves Araújo, Leonardo Emanuel de Oliveira Costa, Janaína dos Santos Nascimento.Sobrevivência de Salmonella Enterica em Fórmulas Lácteas Infantis Sob Diferentes Condições de Armazenamento e Aquecimento.. In: Anais do 12을 Congresso Latinoamericano de Microbiologia e Higiene de Alimentos - MICROAL 2014 [= Blucher Food Science Proceedings, num.1, vol.1]. São Paulo: Editora Blucher, 2014.

DOI 10.5151/foodsci-microal-103
} 
banho-maria a $60^{\circ} \mathrm{C}$ por 5 min resultou na redução de cerca de $1 \log \mathrm{ufc} / \mathrm{ml}$ em ambas as fórmulas. Já o aquecimento a $60^{\circ} \mathrm{C}$ por $10 \mathrm{~min}$ resultou em uma queda de 2,3 e 2,8 log ufc/ml nas fórmulas F1 e F2, respectivamente. Quando submetidas ao aquecimento a $70^{\circ} \mathrm{C}$ por $5 \mathrm{~min}$, observou-se, em

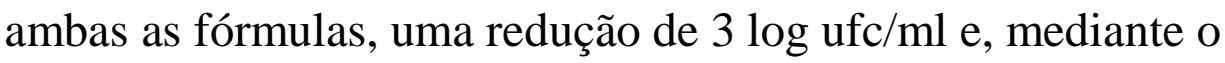
aquecimento por $10 \mathrm{~min}$, a redução foi de 3,7 e 4,0 log ufc/ml para as fórmulas $\mathrm{F} 1$ e F2, respectivamente. $\mathrm{O}$ aquecimento em forno de microondas mostrou ser a forma mais eficiente de redução da população de Salmonella nas FLI, uma vez que não foi detectada contagem celular após o aquecimento por 30, 45, 60 e 90 segundos. Esses resultados sugerem que FLI contaminadas durante a etapa de preparo podem apresentar um crescimento bacteriano elevado já nas primeiras $24 \mathrm{~h}$ se mantidas em temperatura ambiente e que mesmo a refrigeração adequada e algumas formas de aquecimento podem não ser suficientes para inibição completa de S. enterica.

Palavras-Chave: fórmulas lácteas infantis, Salmonella enterica, armazenamento, aquecimento

Agência de Fomento: IFRJ 